\title{
PENGARUH MODEL PEMBELAJARAN CONTEXTUAL TEACHING AND LEARNING (CTL) BERBASIS PROGRAM MATLAB TERHADAP HASIL BELAJAR PESERTA DIDIK PADA MATERI GAYA KELAS VIII SMPN 3 NARMADA 2020/2021
}

\author{
Agil triyadin ${ }^{1)}$, Islahudin ${ }^{1)}, Z^{\prime}$ ulkarnain ${ }^{1)}$ \\ 1)Program Studi Pendidikan Fisika, FKIP, Universitas Muhammadiyah Mataram, Mataram, NTB, Indonesia \\ Corresponding author : Zulkarnain \\ E-mail : dzul9787@gmail.com
}

Diterima 09 November 2020, Disetujui 15 November 2020

\begin{abstract}
ABSTRAK
Tujuan dari penelitian ini adalah ingin mengetahui Pengaruh model pembelajaran contextual teaching and learning $(\mathrm{CTL})$ berbasis program matlab terhadap hasil belajar peserta didik pada materi gaya kelas VIII SMPN 3 Narmada 2020/2021. Penelitian ini merupakan penelitian quasi experiment researcha dengan metode control grup design subjek dalam penelitian ini adalah seluruh siswa kelas VIII SMPN 3 Narmada. Sampel dalam penelitian di ambil secara purposive sampling dengan kelas VIII A sebagai kelas experiment yang berjumlah 25 orang siswa dan kelas VIII B sebagai kelas control yang berjumlah 25 orang siswa. Tes yang dibuat berupa soal pilihan ganda. Instrument yang digunakan berupa tes yang telah diuji kelayakan. Berdasarkan hasil perhitungan uji maka diperoleh thitung sebesar 5.276 sedangkan nilai trabel pada taraf signifikan $5 \%$ dengan $\mathrm{dk}=\mathrm{n}_{1}+\mathrm{n}_{2}-2=25+25-2=48$ diperoleh harga trabel sebesar 2.457. Jadi dari hasil perhitungan dapat disimpulkan bahwa thitung $>$ tabel maka dapat diakatakan hipotesis (Ha) diterima. Ini berarti bahwa " ada pengaruh contextual teaching and learning (CTL) berbasis program matlab peningkatan hasil belajar kelas VIII SMPN 3 Narmada materi gaya tahun pelejaran 2020/2021.
\end{abstract}

Kata Kunci: contextual teaching and learning (CTL); program matlab; hasil belajar siswa.

\begin{abstract}
The purpose of this study was to determine the effect of the contextual teaching and learning (CTL) model based on the matlab program on student' learning outcomes at the material of force for eight graders of SMPN 3 Narmada 2020/2021. This research is a quasi-experimental research with a control group method. The subjects in this study were all the eight graders of SMPN 3 Narmada. The samples in this study were taken through purposive sampling, one was the class of VIII-A as the experimental group which consisted of 25 students and the other one wasc the lass of VIII-B as the control group,which had totally 25 students. The test was made in the form of multiple choice questions. The instrument used was a test that had been tested for its feasibility. Based on the results of the test calculations, it found that the value of $t_{\text {count }} 5,276$ while the table value was at a significant level of $5 \%$ with $\mathrm{dk}=\mathrm{n} 1+\mathrm{n} 2-2=25+25-2=48$, the the value of table was 2.457 . Hence, based on the calculation result, it could be concluded that tcount $>$ table. In other words, it can be said that the hypothesis $(\mathrm{Ha})$ was accepted. This means that "there was an effect of contextual teaching and learning (CTL) model based on the matlab program in improving students' learning outcomes in the material of force for the eight graders of SMPN 3 Narmada academic year 2020/202.
\end{abstract}

Keywords: contextual teaching and learning (CTL); matlab program; students' learning outcomes

\section{PENDAHULUAN}

Pendidikan merupakan usaha penting yang harus dijalankan oleh setiap manusia karena dapat membantu menjadi pribadi mandiri yang utuh, produktif, dan kreatif. Menurut purwanto (2011) pendidikan ialah segala usaha orang dewasa dalam pegaulannya dengan anak-anak untuk memimpin perkembangan jasmani dan rohaninya kearah dewasaan. Pendidikan merupakan pembentukan karakter seorang individu dalam menghadapi tantangan hidup. Undang-undang Republik Indonesia Nomor 20 tahun 2003 Bab II 3 tentang sisdiknas mengatakan bahwa pendidikan Nasional berfungsi mengembangkan kemampuan dan bentuk watak serta peradaban bangsa yang martabat dalam rangka mencerdaskan kehidupan bangsa, bertujuan untuk berkembangnya potensi peserta didik agar 
menjadi manusia beriman bertakwa kepada Tuhan yang Maha Esa, berkhalak mulia, berilmu, cakap, kreatif, mandiri, dan menjadi warga Negara yang demokrasi serta bertangung jawab. Perkembangan pendidikan juga memiliki pengaruh terhadap lokasi sumber daya pendidikan.

Leonard, (2013) sumber daya pendidikan adalah semua faktor yang dapat dimanfaatkan oleh pengelola pendidikan dalam rangka mencapai tujuan yang ditetapkan secara efektif dan efisien. Oleh sebab itu, pendidikan harus dirancang secara sistematis agar melahirkan generasi-generasi yang unggul. Maju dan mundurnya suatu Negara juga ditentukan oleh bebrapa faktor dan diantaranya adalah faktor pendidikan.

Solusi dalam menyelesaikan masalah dalam pendidikan pada materi fisika yang dikaitkan langsung dengan kehidupan sehari hari atau dipraktikumkan berupa penggantian model pembelajaran serta metodenya. Model pembelajaran yang menekankan pada hubungan antara materi dan kehidupan sehari - hari adalah model pembelajaran Contextual Teaching and Learning (CTL).. Sedangkan metode yang menunjang pelaksanaan model pembelajaran Contextual Teaching and Learning (CTL). adalah eksperimen. Dua hal tersebut, sangat aktif menjadi solusi apabila perangkat lain tidak mendukung. Perangkat lain tersebut anatara lain guru yang memiliki pedagogik terhadap pemebelajaran kognitif, professional dalam mengajar, dan lain - lain.

Model pembelajaran Contextual Tearching and learning (CTL) merupakan salah satu pendekatan pemnelajaran yang dilibatkan peserta didik secara langsung dalam pengalaman dan tidak hanya mencatat saja. Konsep dan asas model pembelajaran Contextual Tearching and learning (CTL) mengarah pada menciptakan peserta didik yang kritis dan kreatif. Melalui model CTL peserta didik diberi kesempatan untuk mencari dan menemukan sendiri konsep berdasarkan topic yang ditentukan. Kemudian peserta didik menghubungkan dari pengalaman yang pernah diperoleh di sekolah dengan kejadian disekitarnya. Pengalaman yang diperolah peserta didik sendiri akan menjadikan pemahaman peserta didik terhadap materi yang diperoleh dapat melekat kuat di ingatanya. Karakteristik model pembelajaran Contextual Tearching and learning (CTL) adalah kerjasama, saling menunjang, menyanangkan, tidak membosankan, belajar lebih bergaira, terintegrasi, menggunakan berbagai sumber dan membudayakan peserta didik aktif (Novitasari, 2015).
Berdasarkan hasil observasi di SMP Negri 3 Narmada peneliti menemukan suatu permasalahan pada proses pembelajran mata pelajaran IPA terpadu khususnya mata pembelajaran fisika pada materi gaya dimana terkendalanya dalam menyelesaiakan pelajaran pada materi Gaya. Pembelajaran fisika, sering kali kata "fisika" dianggap sesuatu yang sulit, sesuatu yang abstrak, dan sesuatu yang menakutkan. Dikarenakan hanya dipandang dengan rumus-rumus saja, khayalan dengan penggambaran yang pudar,. fisika tidak pernah dipandang dengan pandangan sederhana dan menyenangkan seperti bola, kotak, sepatu, sebagainya. Sehingga dengan penggambaran seperti itu, dapat menimbulkan adanya ketertarikan dan keterkaitan antara materi Fisika dan kehidupan sehari-hari.

Oleh karena itu perlu adanya inovasi baru dalam proses pembelajaran untuk diterapkan dalam proses pembelajaran khususnya materi gaya yaitu dengan model pembelajaran serta metodenya. Model pembelajaran yang menekankan pada hubungan antara materi dan kehidupan sehari - hari adalah model pembelajaran Contextual Teaching and Learning (CTL). Sedangkan metode yang menunjang pelaksanaan model pembelajaran Contextual Teaching and Learning (CTL) adalah media pembelajaran. Media pembelajaran dapat digunakan sebagai alternatif dalam melaksanakan proses pembelajaran pada saat menurunya semanagat belajar dan tentunya untuk membantu meningkatkan kualitas pembelajaran serta pemahaman peserta didik. Banyaknya media seperti Power Point, Adobe Flash dan masih banyak lagi. Peneliti memilih dan menerapkan media pembelajarn dengan software GUI (Guide User Interface) Matlab dalam pembelajaran IPA Terpadu khususnya materi gaya.

Menurut Cucu Suhana (2014: 61) menjelaskan " media pembelajaran adalah segala bentuk prangsang yang dapat merangsang peserta didik dan alat yang disediakan guru untuk mendorong peserta didik belajar secara cepat yang tidak membuang waktu, tepat, mudah, benar, dan tidak terjadinya verbalisme.

Hal ini sesuai dengan hasil penelitian yang sudah dilakukan oleh Rostina Sundayana (2006 : 13) karakteristik media pembelajaran dapat di klasifikasikan menjadi beberapa sudut mana melihatnya : dilihat dari sifatnya, media dapat dibagi kedalam media audiofisual, dilihat dari kemampuanya dan dilihat dari cara atau teknik pemakaianya.

Berdasarkan pertimbangan masalah yang dihadapi peserta didik pada proses 
pembelajaran IPA Terpadu khususnya mata pelajaran fisika SMP/MTS serta kelebihan yang ada pada GUI Matlab maka penulis ingin merangsang dan membangkitkan indra, penglihatan, pendengaran, peraba, maupun penciuman atau kesesuaian dengan tingkatan belajar peserta didik materi gaya dengan menggunakan GUI Matlab dengan harapan dapat membantu peserta didik dalam pemahaman materi sehingga kegiatan pembelajaran lebih efektif dan efisien.

Untuk dapat memenuhi semua harapan tersebut, dalam kesempatan ini peneliti mengangkat penelitian yang berjudul "Pengaruh Model Pembelajaran Contextual Teaching And Learning (CTL) Berbasis Program Matlab Terhadap Hasil Belajar Peserta Didik pada Materi Gaya Kelas VIII SMPN 3 Narmada 2020/2021".

\section{METODE PENELITIAN Rancangan penelitian}

Penelitian ini termasuk jenis quaisi eksperimen. Menurut Riduwan (2014) penelitian eksperimen adalah suatu penelitian yang berusaha mencari pengaruh variabel bebas terhadap variabel terikat dalam kondisi yang terkontrol secara ketat.

Pendekatan yang digunakan dalam penelitian ini adalah pendekatan kuantitatif dan kualitatif dimana pendekatan kuantitatif yaitu data yang diperoleh peneliti dalam bentuk angka, sedangkan pendekatan kualitatif adalah data yang diperoleh dalam bentuk kalimat, gambar atau pendekatan kuantitatif berkaitan dengan mengukur hasil belajar peserta didik sebagai hasil pembelajaran (Sugiyono, 2014).

Adapun rancangan penelitian yang digunakan adalah Pretest Posttest Control Group Design, dimana pada rancangan ini sampel dibagi menjadi dua kelompok yaitu kelompok pertama sebagai kelas eksperimen dan kelompok kedua sebagai kelas kontrol. Dalam hal ini dapat dilihat perbedaan pencapaian antara kelompok eksperimen dengan kelompok kontrol sebagai berikut:

Tabel 1. Metode pretest-posttest control Group Desaign

\begin{tabular}{|c|c|c|c|}
\hline Kelas & $\begin{array}{c}\text { Pretet } \\
s\end{array}$ & $\begin{array}{l}\text { Treatmen } \\
t\end{array}$ & $\begin{array}{c}\text { Posttes } \\
t\end{array}$ \\
\hline $\begin{array}{l}\text { Kelas } \\
\text { eksperimen } \\
t\end{array}$ & 01 & $x$ & 02 \\
\hline $\begin{array}{l}\text { Kelas } \\
\text { control }\end{array}$ & 03 & - & 04 \\
\hline
\end{tabular}

(Sugiyono, 2014)

Keterangan:

$\mathrm{X}$ :Pembelajaran dengan model Contextual Teaching And Learning (CTL) Berbasis Matlab
O1 :Pretest yang dikenakan pada kelas eksperimen (pemberian tes /sebelum materi gaya).

O2 :Posttest yang dikenakan pada kelas eksperimen (pemberian tes setelah kelas eksperimen mendapat pembelajaran dengan model Contextual Teaching And Learning (CTL) Dalam Pembelajaran Berbasis Matlab).

O3 :Pretestyang dikenakan pada kelas kontrol (pemberian tes sebelum materi gaya).

O4 :Posttest yang dikenakan pada kelas kontrol (pemberian tes setelah kelas kotrol mendapat pembelajarn tanpa model Contextual Teaching And Learning (CTL) Berbasis Matlab).

\section{Lokasi dan Waktu Penelitian}

Penelitian ini dilaksakan di SMP SMPN 3 Narmada peserta didik kelas VIII.

Penelitian ini direncanakan pada bulan 10 Agustus 2020 pada semester ganjil Kelas VIII SMPN 3 Narmada Tahun Pelajaran 2020/2021.

\section{Penentuan Subjek Penelitian \\ 1. Populasi}

Menurut Arikunto, (2015:173) populasi adalah keseluruhan subjek penelitian. Apabila seseorang ingin meneliti semua elemen yang ada dalam wilayah penelitian, maka penelitiannya merupakan penelitian populasi. Dalam penelitian ini yang menjadi populasinya adalah semua peserta didik kelas VIII semester ganjil SMPN 3 Narmada Tahun pelajaran $2020 / 2021$.

\section{Sampel}

Teknik pengambilan sampel yang digunakan adalah teknik Purposive Sampling. Menurut Sugiyono (2014) Purposive Sampling merupakan teknik penentuan sampel dengan pertimbangan-pertimbangan tertentu, dan berdasarkan rekomendasi dari guru. Pada penelitian ini akan digunakan kelas VIII-A dan kelas VIII-B, yang berjumlah masing-masing 25 siswa sebagai sampel karena direkomendasikan oleh guru mata pelajaran.

\section{Teknik Pengumpulan Data}

Untuk mengumpulkan data dalam penelitian eksperimen ini dilakukan pengumpulan data berdasarkan tekniknya yaitu sebagai berikut :

\section{Observasi}

Lembar observasi aktivitas peserta didik dengan menggunakan model Contextual Teaching And Learning (CTL) ini bertujuan untuk melihat bagaimana aktivitas peserta didik pada saat proses pembelajaran berlangsung dan lembar observasi aktivitas guru dengan 
menggunakan model Contextual Teaching And Learning (CTL) ini bertujuan untuk melihat bagaimana aktivitas guru selama proses belajar mengajar. Observasi ini dibuat dalam bentuk checklist.

\section{Tes}

Menurut Arikunto (2006) "tes merupakan alat atau prosedur yang digunakan untuk mengetahui atau mengukur sesuatu dalam suasana, dengan cara dan aturan-aturan yang sudah ditentukan." Data tes yang dihasilkan berupa rata-rata gain skor pretes dan postes kemampuan hasil belajar

\section{Dokumentasi}

Dokumentasi adalah catatan pristiwa yang berbentuk tulisan atau karya-karya monumental dari seseorang. Sebagai salah satu faktor untuk mendukung hasil penelitian yang dapatkan penelitian.

\section{Variabel Penelitian}

Menurut Sugiyono

(2014:38)

menjelaskan bahwa variabel penelitian adalah suatu atribut atau sifat atau nilai dari orang, obyek atau kegiatan yang mempunyai variasi tertentu yang ditetapkan oleh peneliti untuk dipelajari dan kemudian ditarik kesimpulannya.

\section{Variabel Bebas}

Variabel bebas adalah variabel yang dapat mempengaruhi atau menjadi penyebab perubahan atau timbulnya variabel dependen/terikat (Sugiyono, 2014:39). Biasanya variabel bebas akan dimanipulasi, diamati dan diukur dengan tujuan untuk mengetahui sejauh mana pengaruhnya terhadap variabel lainnya. Variabel bebas dalam penelitian ini adalah model Contextual Teaching And Learning (CTL) Berbasis Program Matlab.

\section{Variabel Terikat}

Dalam sebuah penelitian, variabel terikat diamati dan diukur untuk mengetahui pengaruh dari variabel bebas. Disini variabel terikat juga disebut dengan variabel dependen yaitu variabel yang dipengaruhi atau yang menjadi akibat, karena adanya variabel bebas. Variabel tergantung berfungsi untuk mengetahui pengaruh dari variabel bebas (sugiyono, 2014:39). Variabel terikat dalam penelitian ini adalah terhadap hasil belajar peserta didik pada materi gaya Kelas VIII SMPN 3 Narmada 2020/2021.

\section{Instrumen Penelitian}

Menurut Sugiyono (2016), Instrumen penelitian adalah suatu alat yang digunakan untuk mengukur fenomena alam maupun sosial yang diamati. Secara spesifik semua fenomena ini disebut variabel penelitian. Sedangkan menurut Riduwan (2010), Instrumen penelitian adalah seluruh alat pengambilan data yang digunakan dalam penelitian yang mencakup proses pengumpulan data dan teknik penentuan kualitas instrument (validitas dan reabilitas instrument penelitian.

\section{Uji Coba Instrumen penelitian}

\section{a. Uji Validitas}

Valid dan tidaknya soal dan angket dapat dihitung dengan korelasi pearson product

$$
t=\frac{\bar{x}_{1}-\bar{x}_{2}}{\sqrt{\frac{\left(n_{1}-1\right) s_{1}^{2}+\left(n_{2}-1\right) s_{2}^{2}}{n_{1}+n_{2}-2}\left(\frac{1}{n_{1}}+\frac{1}{n_{2}}\right)}}
$$

Keterangan:

$r_{x y} \quad=$ koefisien validitas ( $r$ hitung)

$\sum X=$ jumlah skor item soal tes

$\sum Y=$ skor total peserta

$\mathrm{N} \quad=$ jumlah peserta tes

Hasil $r$ hitung/ rxy yang didapat kemudian di bandingkan dengan table rproduct moment yang disesuaikan dengan jumlah responden, dimana penggunaan $r$ tabel dengan pilihan taraf signifikansi.(M.Isnaini dkk, 2017).

\section{b. Reliabilitas instrumen}

Reabilitas adalah menunjukan bahwa suatu instrument cukupdapat dipercaya untuk digunakan sabagai alat pengumpulan data karena instrument itu sudah baik. Untuk perhitungan dalam reliabilitas penelitian ini digunakan rumus alfa, dimana rumus ini digunakan untuk mencari reliabilitas.

$r_{i}=\frac{k s t^{2}-\sum p i q i}{(k-1) \quad s t^{2}} \ldots$

$\mathrm{K}$ = banyaknya item instrument

$P_{i}=$ proporsi banyaknya subyek yang menjawab pada item ke-i

$q_{i}=1-P_{i}$

$S t^{2}=$ varians skor total

Adapun kriteria koefisien reliabilitas pada

Tabel 2. interprestasi koefisian reliabilitas

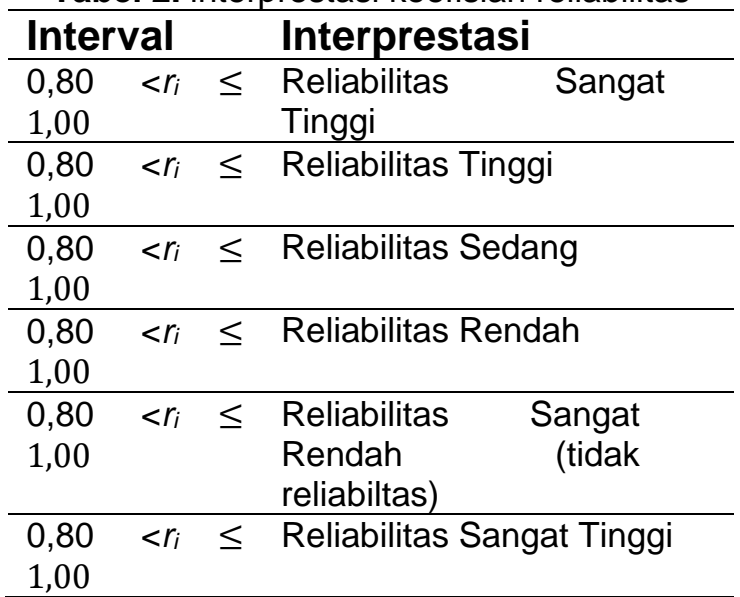




\section{c.Tingkat kesukaran soal}

Untuk menguji tingkat kesukaran digunakan rumus :

$$
\mathrm{P}=\frac{B}{J S}
$$

Keterangan :

$\mathrm{P}=$ Tingkat kesukaran

$\mathrm{B}=$ Banyaknya peserta didik yang menjhawab soal itu dengan benar

$\mathrm{JS}=$ Jumlah seluruh peserta didik peserta tes Menurut Arikunto (2002) indeks

kesukaran diklasifikasikan sebagai berikut :

$$
\begin{array}{ll}
0,00 & =\text { Terlalu sukar } \\
0,01-0,30 & =\text { Sukar } \\
0,31-0,70 & =\text { Sedang } \\
0,71-1,00 & =\text { Mudah } \\
\geq 1,01 & =\text { Sangat mudah }
\end{array}
$$

Item soal yang digunakan yaitu yang mempunyai tingkat kesukaran sukar, sedang dan mudah.

\section{d. Daya pembeda soal}

Rumus yang digunakan untuk menguji daya beda (Arikunto, 2002) adalah:

$$
\begin{aligned}
& \mathrm{D}=\frac{B_{A}}{J_{A}}-\frac{B_{B}}{J_{B}} \ldots \ldots \ldots \ldots \ldots \ldots \ldots \\
& \text { Keterangan : } \\
& \mathrm{D}= \text { indeks diskriminasi } \\
& \mathrm{BA}= \text { banyaknya peserta tes kelompok atas } \\
& \text { yang menjawab soal dengan benar } \\
& \mathrm{BB}= \text { banyaknya peserta kelompok bawah yang } \\
& \text { menjawab soal dengan benar } \\
& \mathrm{JA}= \text { jumlah peserta tes pada kelompok atas } \\
& \mathrm{JB}= \text { jumlah peserta tes pada kelompok bawah }
\end{aligned}
$$

\section{Teknik Anilisis Hasil Belajar}

\section{a. Uji Normalitas}

Sebelum data hasil belajar peserta didik yang diperoleh dari lapangan dianalisis lebih lanjut, terlebih dahulu diuji normalitas. Tujuan dari uji normalitas adalah untuk mengetahui apakah data post test atau kemampuan akhirpeserta didikpada kedua kelas berasal dari populasi normal atau tidak.

Uji normalitas pada penelitian ini menggunakan rumus Chi-kuadrat.

$$
\chi^{2}=\sum_{i=1}^{k} \frac{\left(f_{0}-f_{h}\right)^{2}}{f_{h}}
$$

Keterangan:

$x^{2}$ : hargachi-kuadrat

$f_{o}$ : frekuensi data hasil observasi

$f_{h}$ : frekuensi yang diharapkan

$k$ : banyaknya kelas interval

Pengujian normalitas dengan ChiKuadrat memiliki kriteria pengujian, jika $X^{2}$ hitung $\leq X^{2}$ tabel pada taraf sinifikan $5 \%$ maka distribusi data nilai hasil belajar (post test) dinyatakan berdistribusi secara normal sedangkan jika $X^{2}$ hitung $\geq X^{2}$ tabel maka dinyatakan tidak terdistribusi secara normal.

\section{b. Uji Homogenitas}

Uji homogenitas dilakukan untuk mengetahui apakah kedua data yang digunakan dalam penelitian ini homogen atau tidak homogen. Pengujian homogenitas menggunakan uji-F dengan rumus sebagai berikut:

$F=\frac{\text { Varians terbesar }}{\text { Varians terkecil }}$

\section{c. Uji Hipotesis (uji-t)}

Untuk membuktikan signifikansi perbedaan hasil belajar peserta didik yang diajarkan menggunakan model model Contextual Teaching And Learning (CTL) Dalam Pembelajaran Berbasis Matlab dengan peserta didik yang diajarkan menggunakan metode visual bervariasi, perlu diuji secara statistik dengan t-test berkorelasi (related). Rumus yang digunakan adalah berikut (Sugiyono, 2014):

$$
t=\frac{\bar{x}_{1}-\bar{x}_{2}}{\sqrt{\frac{\left(n_{1}-1\right) s_{1}^{2}+\left(n_{2}-1\right) s_{2}^{2}}{n_{1}+n_{2}-2}\left(\frac{1}{n_{1}}+\frac{1}{n_{2}}\right)}}
$$

Keterangan :

$\overline{X_{1}} \quad=$ Nilai rata - rata kelompok eksperimen

$\overline{X_{2}} \quad=$ Nilai rata-rata kelompok kontrol

$S_{1}{ }^{2}=$ Standar deviasi nilai kelompok eksperimen

$S_{2}{ }^{2} \quad=$ Standar deviasi nilai kelompok kontrol

$n_{1}$ = Jumlah peserta didik dalam kelompok eksperimen

$n_{2} \quad$ = Jumlah peserta didik dalam kelompok kontrol

Dengan ketentuan jika thitung $>$ tabel maka hipotesis Ha diterima dan Ho ditolak dan jika thitung $<\mathrm{t}_{\text {tabel }}$ maka hipotesis nol (Ho) diterima dan Ha ditolak.

\section{Pembahasan}

Secara umum, hasil penelitian ini telah membuktikan hipotesis yang diajukan yaitu tertdapat pengaruh yang signifikan hasil belajar fisika siswa yang belajar dengan menggunakan contextual teaching and learning (CTL) berbasis program matlab dan siswa yang menggunakan metode pembelajaran konvesional. Sebelum melakukan uji hipotesis terlebih dahulu melakukan uji analisis data yaitu melakukan uji normalitas data hasil belajar kelas eksperimen dilakukan dengan cara 
membandingkan hasil $x^{2}$ hitung dengan $x^{2}$ tabel, pada taraf signifikan $5 \%$ maka distribusi data eksperimen dan kelas control dapat dinyatakan terdistribusi normal. Dengan demikian kelas dapat dinyatakan terdistribusi normal.

Untuk uji homogenitas berdasarkan hasil perhitungan uji homogenitas pada kedua kelas diperoleh bahwa nilai kelas eksperimen dan kelas control dapat dikatakan homogen. Jadi berdasarkan kriteria yang ada, jika $\mathrm{F}_{\text {hitung }}<$ $F_{\text {tabel }}$ maka kedua kelas dapat dikatakan memiliki varians yang sama, yang menandakan kedua kelas homogen pada taraf signifikan $5 \%$.

Sesuai hasil penelitian yang diperoleh dari analisis data dan pengujian hiotesis yang telah menunjukan bahwa " ada pengaruh menggunakan contextual teaching and learning (CTL) berbasis program matlab peningkatan hasil belajar kelas VIII SMPN 3 Narmada materi gaya tahun pelejaran 2020/2021. Perbedaan signifikan ini terlihat dari analisi uji hipotesis yang telah dilakukan dengan menggunakan uji$\mathrm{t}$ hasil analisis menunjukan bahwa hasil uji-t diperoleh thitung $=5.276$. . Hasil uji-t tersebut kemudian dikonsultasikan pada tabel. Dengan taraf signifikan $5 \%$ dan $\mathrm{db}=30$ diperoleh tabel 2.457 karena thitung $\geq$ tabel. Maka hipoteis $\mathrm{Ha}$ diterima, dengan demikian ada pengaruh ada pengaruh menggunakan contextual teaching and learning (CTL) berbasis program matlab peningkatan hasil belajar kelas VIII SMPN 3 Narmada materi gaya tahun pelejaran 2020/202. Hal-hal obserfasi proses belajar siswa selama proses belajar berlangsung dilihat bahwa ada perbedaan proses belajar siswa dengan penerapan ada pengaruh menggunakan contextual teaching and learning (CTL) berbasis program matlab peningkatan hasil belajar kelas VIII SMPN 3 Narmada materi gaya tahun pelejaran 2020/2021.dan hasil obserfasi kegiatan belajar siswa, memperlihatkan bahwa penyampaian tujuan dan motifasi ,aktiftas pembelajaran serta tanggapan terhadap penghargaan kategori baik.

Peningkatan yang diperoleh dari hasil kegiatan belajar mengajar disebabkan oleh beberapa hal antara lain siswa telah terbiasa dalam proses belajar mengajar yang menggunakan visual masalah sehingga ada perasaan tertarik dan sunguh-sunguh dalam mengikuti proses belajar mengajar. Begitu juga proses diskusi atau Tanya jawab terjadi komunikasi yang baik antara guru dan siswa tentang materi yang disampaikan. Hal ini berpengaruh terhadap hasil belajar pada siswa.

Berdasarkan data hasil observasi kegiatan belajar mengajar penerapan ada pengaruh menggunakan contextual teaching and learning (CTL) berbasis program matlab. Menunjukan siswa mengalami sesuatu bentuk perubahan yang baru secara keseluruhan sebagai hasil pengalamanya sendiri dalam interaksi dangan lingkungan.

Berdasarkan hasil penelitian bahwa, ada perbedaan yang signifikan antara kelas eksperimen dengan kelas control. Hal ini terlihat pada kelas eksperimen tampak bahwa siswa krestif dan memahami apa yang diajarakan oleh guru dan siswa lebih siap mengerjakan soal latihan yang diberikan oleh guru. Sedangkan kelas control siswa fakum dan banyak diam. Dalam proses belajar mengajar.metode megajar merupakan hal penting. Sebab metode megajar merupakan faktor penunjang dan penyampaian materi pembelajaran yang akan mampu meningkatkan hasil belajar. Setiap metode pembelajaran mempunyai kelemahan dan kelebihan daya cocok yang berbeda bagi setiap siswa.oleh karena itu kemampuan guru dalam memiliki metode yang sesuai dengan materi pembelajaran dan kondisi fisik siswa akan sangat mempengaruhi hasil belajar.

Paparan tersebut menjadi alasan pendukung bahwa ada pengaruh menggunakan contextual teaching and learning (CTL) berbasis program matlab, memang logis mempengaruhi baik terhadap hasil belajar dibandingkan dengan model pembelajaran konvesional yang hanya mentransfer pengetahuan tampa memperhatikan potensi siswa.

\section{SIMPULAN DAN SARAN Simpulan}

Hasil penelitian dan pembahasan yang telah diungkapkan pada bagian sebelumnya, maka dapat diambil kesimpulan bahwa terdapat pengaruh yang signifikan hasil belajar Fisika siswa kelas eksperimen dengan menggunakan ada pengaruh menggunakan contextual teaching and learning (CTL) berbasis program matlab peningkatan hasil belajar kelas VIII SMPN 3 Narmada materi gaya tahun pelejaran $2020 / 2021$. Hal ini bisa dilihat dari nilai rata-rata kelas eksperiemen pre test yaitu 60 dan post test yaitu 85 , sedangkan kelas control belajar nilai rata-rata pre test yaitu 60 dan post test yaitu 72.

Berdasarkan hasil perhitungan uji hipotesis dengan menggunakan rumus uji-t maka diperoleh thitung sebesar 5.276 sedangkan nilai tabel $\mathrm{p}$ ada taraf signifikan $5 \%$ dengan $\mathrm{dk}$ $=\mathrm{n}_{1}+\mathrm{n}_{2}-2=25+25-2=48$ diperoleh harga tabel sebesar 2.457. Jadi dari hasil perhitungan dapat disimpulkan bahwa thitung > tabel maka dapat diakatakan hipotesis $(\mathrm{Ha})$ diterima. Ini berarti bahwa " ada pengaruh contextual teaching and learning (ctl) berbasis program matlab peningkatan hasil belajar kelas VIII 
SMPN 3 Narmada materi gaya tahun pelejaran 2020/2021.

\section{Saran}

Berdasarkan kesimpulan diatas, maka dapat disarankan sebagai berikut:

1. Bagi siswa, hasil penelitian ini dapat meningkatkan hasil belajar siswa dalam mempelajari mata pelajaran fisika.

2. Bagi guru, sebagai rujukan bagi guru yang ingin menerapkan pembelajaran yang tepat dalam proses belajar mengajar dalam pendidikan.

3. Bagi sekolah, hasil penelitian ini dapat memberikan konstrubusi yang baik dalam rangka perbaikan pembelajaran di sekolah khususnya pembelajaran pendidikan fisika, selain itu, sekolah dapat memberikan rekomendasi kepada guru lain untuk menapkan pembelajaran pendidikan.

\section{DAFTAR PUSTAKA}

Arikunto, S. (2006). Prosedur Penelitian: Suatu Pendekatan Praktik. Rinekacipta.

Arsyad, A. (2017). Media pembelajaran. PT Raja Grafindo Persada.

Away, G. . (2006). The Shortcut Of Matlab Programming. Informatika Bandung.

Bingah, J. (2013). Pengaruh Penerapan Pendekatan Contextual Teaching And Learning (Ctl) Terhadap Hasil Belajar Siswa Pada Materi Perpindahan Panas Di Kelas X Sma Negeri 14 Surabaya. Universitas Negeri Surabaya.

Fauzan, A., \& Ratna Wulan, dan. (2012). Penerapan Pendekatan Contextual Teaching and Learning (Ctl) Berbasis Lesson Study Dalam Meningkatkan Kualitas Pembelajaran Fisika Di Smp Negeri Kota Padang. Jurnal Penelitian Pembelajaran Fisika.

Fauzih, F. (2009). Penggunaan program matlab sebagai Media Pembelajaran Fisika pada Materi Rangkaian Listrik. Isntitut Teknologi Bandung.

Islahudin, I., Darmayanti, N. W. S., \& Zulkarnain, Z. (2017). PENGARUH PEMANFAATAN ALAT PERAGA BERBASIS KEARIFAN LOKAL TERHADAP PENINGKATAN HASIL BELAJAR FISIKA PADA SISWA KELAS VIII DI MTS NURUL IMAN NW KEMBANG KERANG LOMBOK TENGAH TAHUN PELAJARAN 2017/2018. ORBITA: Jurnal Kajian, Inovasi Dan Aplikasi Pendidikan Fisika. https://doi.org/10.31764/orbita.v3i2.1005

Nurul, Zulmi., N. W. S, Darmayanti., Zulkarnain, Z. (2018). Pengembangan Rumfis (Rumus Fisika) Berbasis Program Matlab pada Materi Suhu dan Kalor Untuk Meningkatkan Motivasi Belajar Siswa
SMPN 2 Labuapi Kelas VII Tahun Ajaran 2017/2018. ORBITA: Jurnal Kajian, Inovasi Dan Aplikasi Pendidikan Fisika, $4(1)$.

Sabaryati, J., \& Zulkarnain, Z. (2019). APLIKASI MAP; EFEKTIVITAS MATLAB ALGORITM PROGRAM UNTUK MENINGKATKAN KETERAMPILAN LOGIC PHYSICS MAHASISWA. ORBITA: Jurnal Kajian, Inovasi Dan Aplikasi Pendidikan Fisika. https://doi.org/10.31764/orbita.v5i1.1018

Sugiyono. (2014). Metode Penelitian Pendidikan pendekatan Kuantitatif, Kualitatif dan R\&D. In METODE PENELITIAN ILMIAH.

Suprianto, S., Kholida, S. I., \& Andi, H. J. (2016). PENGARUH PENDEKATAN CONTEXTUAL TEACHING AND LEARNING (CTL) BERBANTUAN MEDIA POWERPOINT TERHADAP PENINGKATAN HASIL BELAJAR IPA FISIKA. Jurnal Penelitian Dan Pembelajaran IPA. https://doi.org/10.30870/jppi.v2i2.427 